\title{
PEMETAAN TINGKAT KERAWANANAN BANJIR MENGGUNAKAN METODE SCORING DAN METODE OVERLAY BERBASIS SISTEM INFORMASI GEOGRAFIS DI KOTA JAMBI
}

\author{
LUSI PRYASTUTI ${ }^{1}$, RUSTAN $^{1 *}$, NASRI MZ ${ }^{2}$ \\ ${ }^{1}$ Program Studi Fisika, Fakultas Sains dan Teknologi, Universitas Jambi \\ Jl. Jambi-Ma.Bulian 36361, Muaro Jambi, Jambi \\ Program Studi Teknik Geofisika, Fakultas Sains dan Teknologi, Universitas Jambi \\ Jl. Jambi-Ma.Buliaan 36361, Muaro Jambi, Jambi \\ *email : rustan.rustan@unja.ac.id
}

\begin{abstract}
Abstrak. Penelitian ini mengenai pemetaan kerawanan banjir di kota Jambi berbasis Sistem Informasi Geospasial (SIG). Penelitian ini bertujuan untuk mengetahui tingkat kerawanan banjir, persebaran lokasi banjir, dan luasan daerah rawan banjir di kota Jambi. Parameter yang digunakan antara lain parameter kemiringan lahan atau lereng, parameter ketinggian, parameter tutupan lahan, parameter jenis tanah, dan parameter curah hujan tahun 2019. Metode yang digunakan adalah metode penskroran (scoring) dan metode tumpang-tindih (overlay) dengan bantuan perangkat lunak ArcGis. Tingkat kerawanan banjir diklasifikasikan menjadi tiga kategori, yaitu kategori cukup rawan, kategori rawan, dan kategori sangat rawan. Hasil yang diperoleh pada penelitian ini adalah sebagian besar Kota Jambi memiliki tingkat kerawanan banjir pada kategori rawan yaitu seluas 9254.82 ha $(58 \%)$, sedangkan untuk wilayah yang di dominasi cukup aman terhadap banjir adalah kecamatan Jambi Selatan yaitu seluas 2849.14 ha (18\%). Hal ini menunjukkan lebih setengah dari luas wilayah kota Jambi adalah daerah yang rawan banjir sehingga sangat penting untuk melakukan tindakan mitigasi baik mitigasi struktural maupun mitigasi non struktural.
\end{abstract}

Kata kunci: Banjir, Metode Penskoran, Metode Tumpang Tindih, GIS, Pemetaan

\begin{abstract}
This research is about flood vulnerability mapping in Jambi City based on Geographic Information System (GIS). This study is aiming to find out the flood vulnerability level, spatial distribution of flood, and flood prone areas in Jambi City. We used five parameters that affect flood vulnerability, including land slope, land level, land use, soil type, and rainfall during 2019. The method used is the scoring and overlay method with the help of ArcGis software. Flood vulnerability level was divided into three categories, namely quite vulnerable, vulnerable, and very vulnerable. The results obtained in this study are that most of Jambi City has a level of flood vulnerability in the vulnerable category, which is an area of 9254.82 ha $(58 \%)$, while for the area that is dominated quite safe from flooding, Jambi Selatan sub-district, is 2849.14 ha (18\%). This shows that more than half of the Jambi city area is a flood-prone area so it is very important to carry out structural and non-structural mitigation actions.
\end{abstract}

Keywords: Flood, Scoring, Overlay, GIS, Mapping

\section{Pendahuluan}

Banjir merupakan peristiwa yang terjadi karena genangan di daratan sebagai akibat dari luapan air dari sungai yang debit airnya melebihi kapasitas perairannya [1]. Selain akibat dari limpahan sungai, genangan banjir juga dipengaruhi beberapa

JIIF (Jurnal Ilmu dan Inovasi Fisika), ISSN: 2549-0516 
faktor seperti kondisi topografi wilayah yang relatif rendah, terjadinya air laut pasang, berkurangnya kawasan resapan air karena alih fungsi lahan, penggundulan hutan, membuang sampah di sungai, dan mendirikan rumah di bantaran sungai [2][4]. Tumpukan sampah tersebut mengakibatkan aliran air tidak lancar dan terhambatnya proses aliran air, serta dapat menimbulkan pendangkalan sungai. Akibatnya pada saat terjadi hujan lebat air tidak dapat tertampung oleh drainase sehingga dapat menimbulkan banjir pada lokasi pemukiman penduduk. Banjir mengakibatkan rusaknya sarana dan prasarana fisik seperti rumah, tempat ibadah, sekolah, dan gangguan kesehatan [5].

Upaya untuk mengurangi risiko bencana banjir dapat dilakukan dengan melakukan pencegahan atau mitigasi bencana. Mitigasi dalam bencana banjir terbagi menjadi dua macam, yaitu mitigasi secara struktural dan secara non struktural. Dalam mitigasi struktural ada beberapa upaya yang dapat dilakukan seperti membangun tembok pertahanan dan tanggul, serta mengatur kecepatan aliran dan debit air. Mitigasi non struktural dapat dilakukan dengan cara memberikan pelatihan dan penyuluhan, evaluasi tempat rawan banjir, menganalisis data-data yang berkaitan dengan banjir, serta membuat mapping (membuat peta untuk daerah rawan banjir) [6]. Pemetaan ini dapat menggunakan bantuan Sistem Informasi Geografis dengan memanfaatkan perangkat lunak ArcGis, sehingga dapat menghasilkan peta daerah rawan banjir sesuai dengan parameter yang telah ditentukan. Sistem Informasi Geografis (SIG) memiliki kemampuan untuk menyimpan, mengelola dan menampilkan informasi dalam bentuk grafis dengan menggunakan peta [7]. Penelitian terkait pemetaan potensi bencana alam menggunakan SIG sudah banyak dilakukan antara lain pemetaan kerawanan longsor, pemetaan kerawanan gempa bumi, pemetaan kerawanan titik panas yang berpotensi menjadi kebakaran hutan, dan pemetaan kerawanan banjir [8]-[11]. Berdasarkan pada beberapa penelitian sebelumnya penulis tertarik melakukan penelitian mengenai pemetaan daerah rawan banjir di kota Jambi menggunakan metode scoring dan overlay. Metode scoring pada prinsipnya yaitu menghitung bobot dari setiap parameter yang digunakan diantaranya curah hujan, kerapatan sungai, jenis tanah, kemiringan lahan, penggunaan lahan, serta ketinggian atau elevasi. Setelah dilakukan pembobotan langkah selanjutnya adalah proses overlay dimana dalam metode ini akan menampilkan peta digital beserta atributnya dan menghasilkan peta gabungan dari setiap parameter yang telah dipilih yang nantinya akan di analisa menggunakan SIG.

\section{Metode Penelitian}

Objek penelitian ini adalah kota Jambi yang merupakan ibu kota Provinsi Jambi. Kota Jambi terdiri dari 8 kecamatan dan dilalui oleh sungai besar yaitu sungai Batanghari. Pemetaan kerawanan banjir kota Jambi berbasis Sistem Informasi Geografis, yang dibagi menjadi tiga tahap yaitu pembangunan basis data, analisis data, dan penyajian hasil analisis, yang diawali dengan pengumpulan data peta pendukung, studi pustaka serta pengolahan data sekunder yang berkaitan dengan kejadian banjir. Data yang dibutuhkan antara lain data shp kemiringan lahan, data shp ketinggian lahan, data shp tutupan lahan, data shp jenis tanah, dan data curah hujan. Peta pendukung yang dibutuhkan antara lain peta shp administrasi kota Jambi. Data-data tersebut merupakan data sekunder yang diakses di situs www.indonesia-geospasial.com dan data curah hujan diakses melalui situs BMKG di http://dataonline.bmkg.go.id/home. 
Peralatan yang digunakan dalam penelitian adalah satu unit komputer, perangkat lunak ArcGis, dan Microsoft Excel. Setelah diperoleh data maka akan dilakukan overlay atau penggabungan dari beberapa peta, dilajutkan dengan pengskoran dan pembobotan untuk menentukan klasifikasi kerawanan banjir yaitu kelas cukup rawan, kelas rawan, dan kelas sangat rawan.

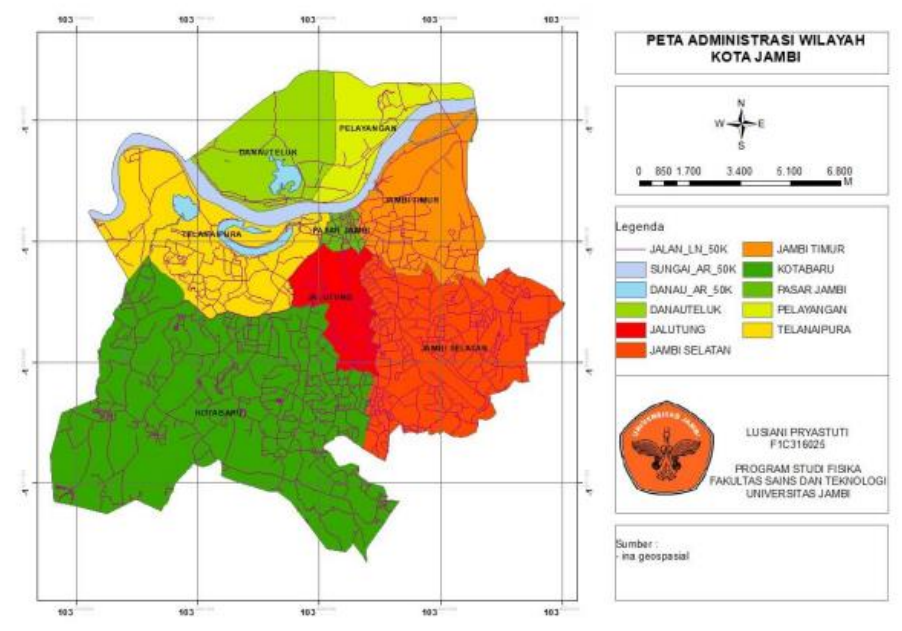

Gambar 1. Peta administrasi kota Jambi

Nilai kerawanan suatu daerah terhadap banjir ditentukan dari total penjumlahan skor seluruh parameter berpengaruh terhadap banjir [12]. Nilai ini dapat ditentukan dengan menggunakan persamaan sebagai berikut :

$$
K=\sum_{i=1}^{n}\left(W_{i} \times X_{i}\right)
$$

keterangan :

$\mathrm{K} \quad=$ Nilai Kerawanan

$\mathrm{W}_{\mathrm{i}} \quad=$ Bobot untuk parameter ke-i

$\mathrm{X}_{\mathrm{i}} \quad=$ Skor kelas pada parameter ke-i

Klasifikasi nilai kerawanan banjir pada penelitian ini berdasarkan pada tabel 1:

Tabel 1. Klasifikasi nilai kerawanan banjir

\begin{tabular}{ccc}
\hline No & Skor $x$ Bobot & Kategori \\
\hline 1 & $>4$ & Sangat Rawan \\
2 & $2-3$ & Rawan \\
3 & $<2$ & Cukup Rawan \\
\hline
\end{tabular}




\section{Hasil dan Pembahasan}

\subsection{Kemiringan Lahan}

Tabel 2. Luasan Kemiringan Lahan Kota Jambi

\begin{tabular}{cccc}
\hline No & Kemiringan $(\%)$ & Keterangan & Luas (Ha) \\
\hline 1 & $0-8$ & Datar & 10596.8 \\
2 & $>8-15$ & Landai & 4815.5 \\
3 & $>15-25$ & Agak curam & 1453.2 \\
4 & $>25-45$ & Curam & 217.4 \\
5 & $>45$ & Sangat curam & 6.06 \\
\hline
\end{tabular}

Sumber : Hasil Digitasi Peta Kemiringan Lahan

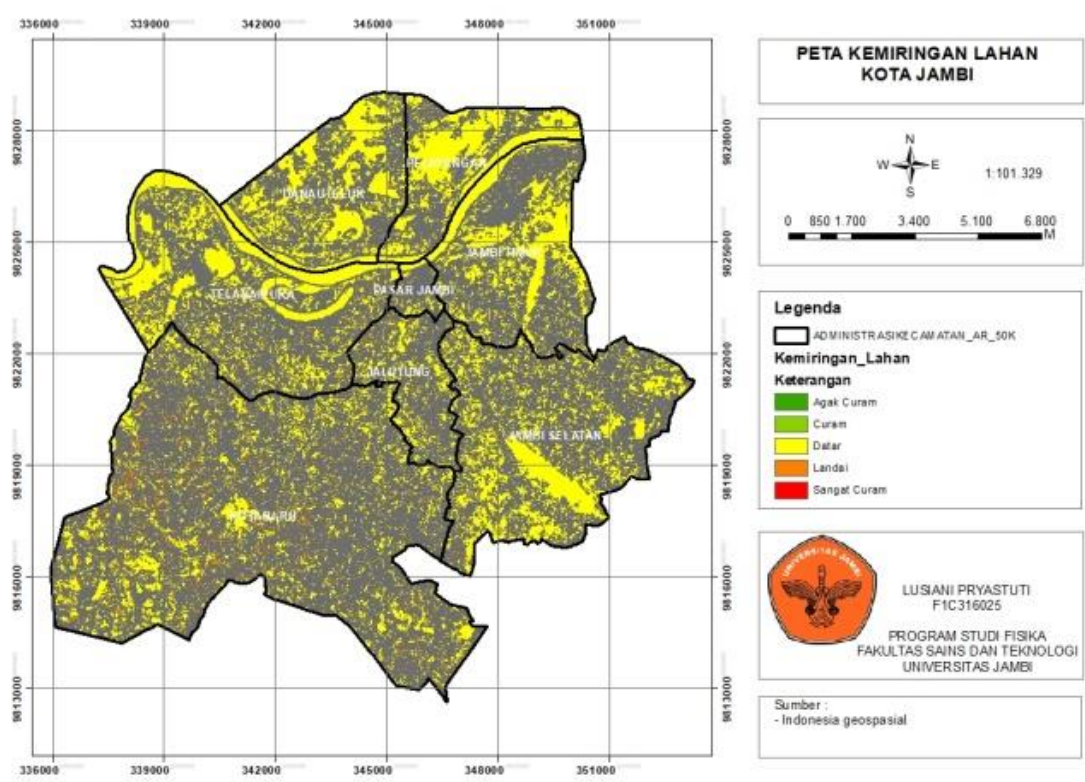

Gambar 2. Peta Kemiringan Lahan Kota Jambi

Berdasarkan pada gambar 2 menunjukkan bahwa Kota Jambi dengan kemiringan 0 $-8 \%$ dengan kategori datar memiliki luasan yang paling besar yaitu sekitar 10596.8 ha dari luas dari luas total wilayah kota Jambi. Wilayah tersebut meliputi keseluruhan kecamatan yang ada di kota Jambi yaitu Kecamatan Danau Teluk, Kecamatan Pelayangan, Kecamatan Telanaipura, Kecamatan Kota Baru, Kecamatan Pasar Jambi, Kecamatan Jambi Timur, serta Kecamatan Jambi Selatan. Kategori dengan luasan paling kecil adalah kategori sangat curam dengan kemiringan $>45 \%$ dengan luasan sekitar 6.06 ha terdapat pada Kecamatan Danau Teluk, Kecamatan Pelayangan, Kecamatan Pasar Jambi, dan Kecamatan Telanaipura. 


\subsection{Ketinggian Lahan}

Ketinggian atau yang biasa disebut elevasi merupakan posisi vertikal suatu objek dari suatu titik tertentu, atau yang biasa digunakan adalah permukaan laut yang disingkat menjadi dpl, dengan satuan yang umum digunakan adalah mdpl (meter di atas permukaan laut). Pada penelitian ini, ketinggian atau elevasi kota Jambi terbagi menjadi tiga kategori yaitu $0-10 \mathrm{mdpl}, 10-50 \mathrm{mdpl}$ dan $50-100 \mathrm{mdpl}$.

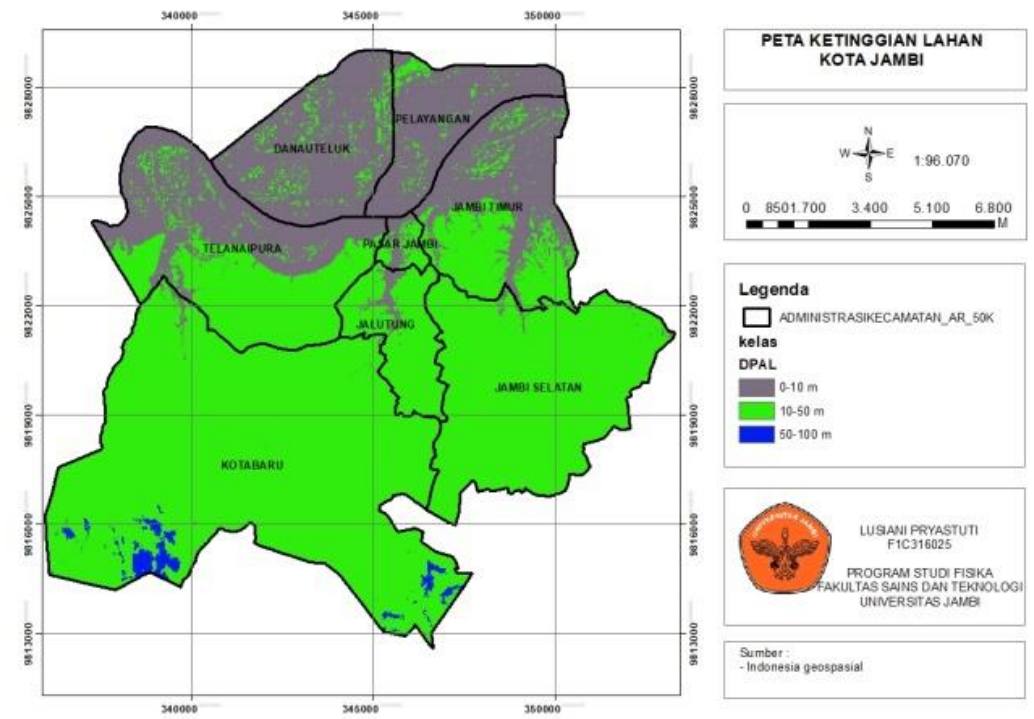

Gambar 3. Peta Ketinggian Kota Jambi

Berdasarkan gambar 3 dapat dikatakan bahwa elevasi kota Jambi didominasi pada ketinggian 10 - 50 mdpl. Ketinggian tersebut terdapat di Kecamatan Jelutung, Kecamatan Jambi Selatan, Kecamatan Telanaipura, sebagian besar dari Kecamatan Pasar Jambi, dan sebagian besar Kecamatan Jambi Timur. Kecamatan yang berada di daerah pinggiran sungai berada pada ketinggian $0-10$ mdpl yaitu Kecamatan Danau Teluk dan Kecamatan Pelayangan. Kecamatan tersebut termasuk dalam dalam kategori wilayah yang rawan banjir. Selain ketinggian lahan yang cukup rendah, namun juga Kecamatan tersebut sangat dekat aliran sungai yang menyebabkan mudah terendam air saat curah hujan melebihi kapasitasnya. Ketinggian lahan 50 - 100 mdpl hanya berada di Kecamatan Kota Baru.

\subsection{Penggunaan Lahan}

Berdasarkan gambar 4 dapat dikatakan bahwa sebagian besar wilayah kota Jambi lahannya digunakan sebagai pemukiman ataupun tempat kegiatan, khususnya pada Kecamatan Pasar Jambi, Kecamatan Telanaipura, Kecamatan Jambi Timur, Kecamatan Jambi Selatan dan Kecamatan Jelutung. Selain itu, untuk pemanfaatan lahan yang paling sedikit adalah lahan hutan rimba hanya berada di Kecamatan Jambi Timur, Kecamatan Kota Baru dan Kecamatan Jambi Selatan. Daerah yang berada di dekat sungai yaitu Kecamatan Pelayangan dan Kecamatan Danau Teluk sebagian besar lahannya digunakan untuk persawahan dan perkebunan. 


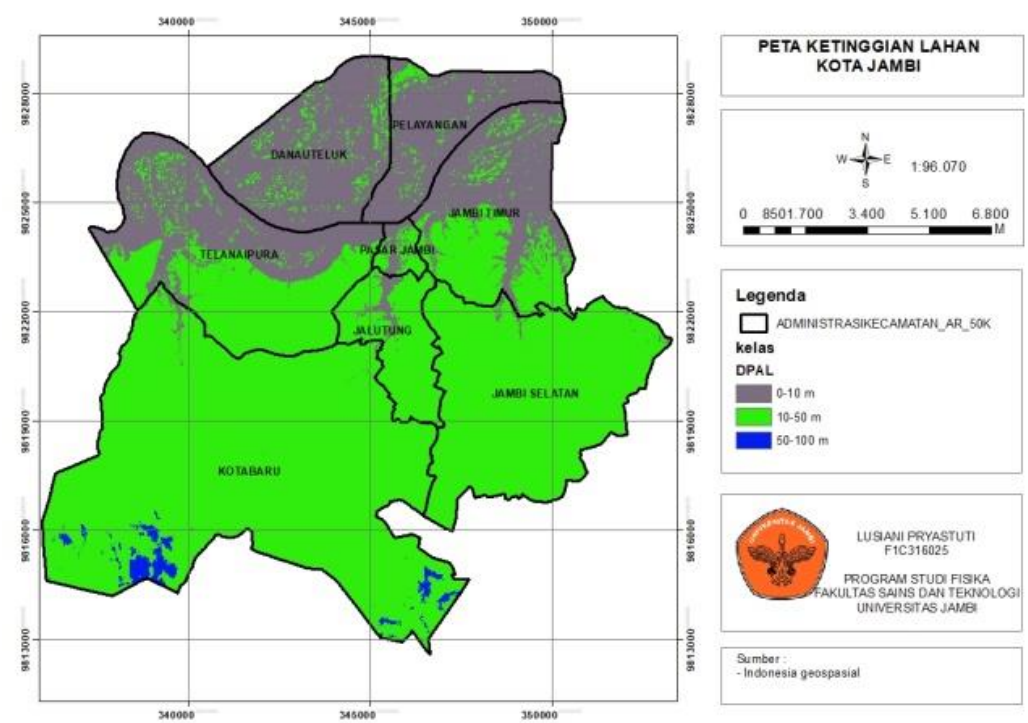

Gambar 4. Peta Penggunaan Lahan Kota Jambi

\subsection{Jenis Tanah}

Tabel 3. Jenis Tanah Kota Jambi dan Luasannya

\begin{tabular}{ccc}
\hline No & Jenis tanah & Luas (ha) \\
\hline 1 & Alluvial gleik & 738.8 \\
2 & Kambisol distrik & 4543.5 \\
3 & Organosol saprik & 2486.5 \\
4 & Podsolik haplik & 5248.3 \\
\hline
\end{tabular}

Sumber : Hasil Digitasi Peta Jenis Tanah

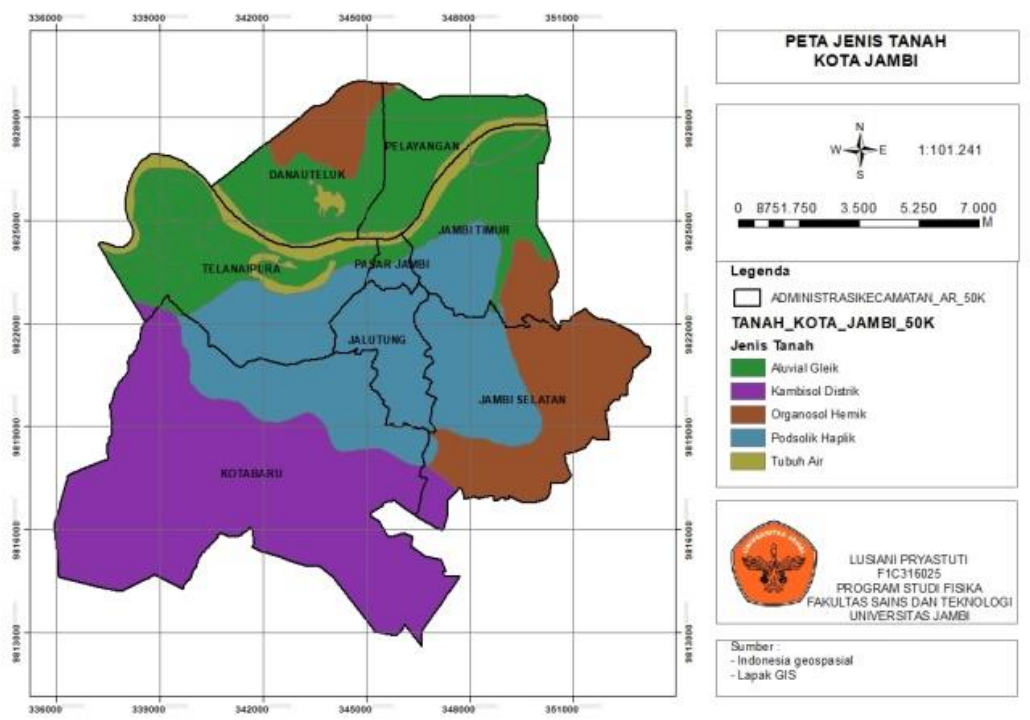

Gambar 5. Peta Jenis Tanah Kota Jambi 
Berdasarkan Gambar 5 dapat dikatakan bahwa terdapat jenis tanah yang paling dominan di kota Jambi adalah jenis tanah podsolik haplik dengan luas area sekitar 5248.3 ha yang terdapat di beberapa Kecamatan diantaranya adalah Kecamatan Jelutung, Kecamatan Pasar, Kecamatan Jambi Timur, Kecamatan Jambi Selatan, Kecamatan Telanaipura, dan Kecamatan Kota Baru. Jenis tanah dengan luas area paling sedikit adalah jenis tanah alluvial gleik dengan luas 738.8 ha, berada di Kecamatan danau Teluk, Kecamatan Jambi Timur, dan Kecamatan Jambi Selatan.

\subsection{Curah Hujan}

Tabel 4. Curah Hujan Kota Jambi Tahun 2019

\begin{tabular}{ccc}
\hline No & Curah Hujan & Luas (ha) \\
\hline 1 & $150-155 \mathrm{~mm} / \mathrm{bln}$ & 1496.02 \\
2 & $155-160 \mathrm{~mm} / \mathrm{bln}$ & 4272.4 \\
3 & $160-165 \mathrm{~mm} / \mathrm{bln}$ & 3943.97 \\
4 & $165-170 \mathrm{~mm} / \mathrm{bln}$ & 7477.4 \\
\hline
\end{tabular}

Sumber : Hasil Digitasi Peta Curah Hujan

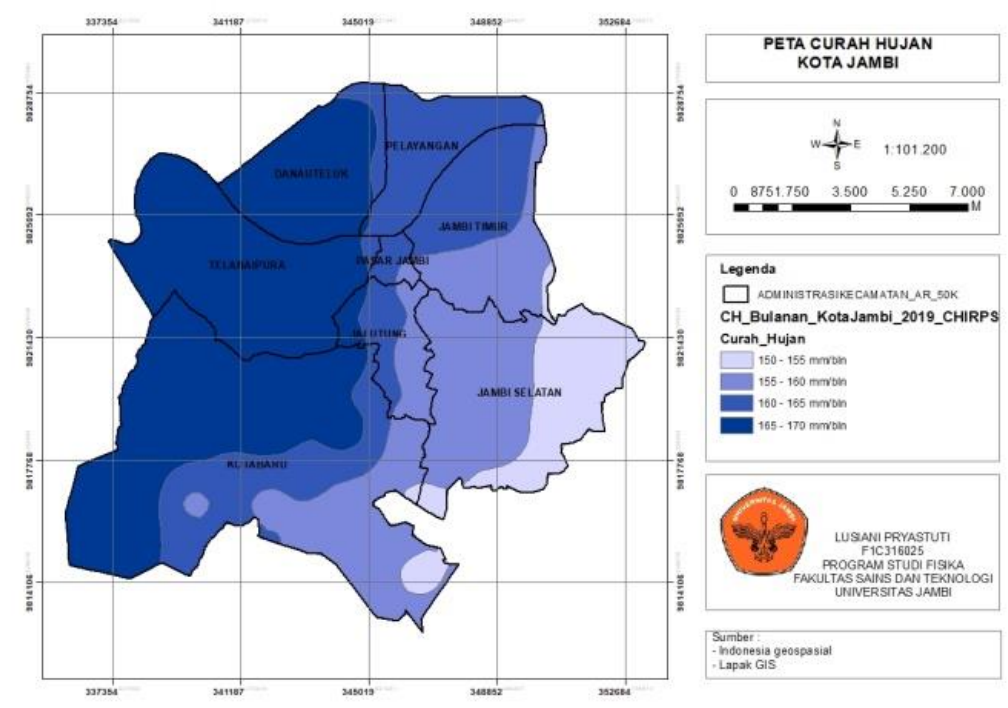

Gambar 6. Peta Curah Hujan Kota Jambi Tahun 2019

Berdasarkan Gambar 6 dapat dikatakan bahwa sepanjang tahun 2019 curah hujan paling tinggi Kota Jambi terjadi di kecamatan Kota Baru, kecamatan Telanaipura, dan kecamatan Danau Teluk yaitu sekitar 165 - $170 \mathrm{~mm} / \mathrm{bln}$ dengan luas area 7477.4 ha. Curah hujan paling rendah yaitu 150 - $155 \mathrm{~mm} / \mathrm{bln}$ terjadi di sebagian kecil Kecamatan Kota Baru, sebagian Kecamatan Jambi Selatan.

\subsection{Analisis Tingkat Kerawanan Banjir Di Kota Jambi}

Tingkat kerawanan banjir di kota Jambi dikategorikan menjadi 3 jenis yaitu kategori rawan, kategori cukup rawan dan kategori sangat rawan. Masing-masing kategori tersebut dapat dijabarkan sebagai berikut.

Daerah dengan kategori banjir sangat rawan merupakan daerah yang menjadi pusat rawan banjir yang paling sering terjadi. Kategori sangat rawan berada di Kecamatan Pelayangan, memiliki luas wilayah sekitar $15.29 \mathrm{~km}^{2}$ serta sangat dekat dengan 
Daerah Aliran Sungai (DAS) Batanghari. Dari data yang diperoleh bahwa Kecamatan ini berada pada ketinggian 0 - 10 mdpl, dengan kemiringan lereng 15$25 \%$ atau kategori cukup curam, dengan jenis tanahnya merupakan jenis aluvial gleik, curah hujan untuk wilayah ini adalah sebesar $160-165 \mathrm{~mm} / \mathrm{bulan}$, serta lahannya didominasi oleh semak belukar.

Daerah banjir dengan kategori rawan merupakan daerah yang memiliki luas wilayah sekitar $77.78 \mathrm{~km}^{2}$ adalah kecamatan Kota Baru. Daerah ini memiliki kemiringan lereng antara $15-25 \%$ atau di kategorikan cukup curam, dengan ketinggian lahan berada antara $10-50 \mathrm{mdpl}$, untuk curah hujannya adalah kategori hujan menengah berkisar antara $165-170 \mathrm{~mm} / \mathrm{bulan}$, serta lahan wilayah tersebut umumnya digunakan sebagai pemukiman penduduk, tempat kegiatan serta semak belukar.

Daerah dengan kategori banjir cukup rawan di dominasi oleh kecamatan Jambi Selatan yang memiliki luas wilayah sekitar $34.07 \mathrm{~km}^{2}$. Daerah ini berada pada kemiringan lereng $15-25 \%$, diperoleh data curah hujannya berkisar antara 150 $160 \mathrm{~mm} /$ bulan dengan kategori hujan menengah, untuk jenis tanah umumya jenis organosol hemik, dan penggunaan lahannya di dominasi oleh pemukiman penduduk serta tempat kegiatan lainnya.

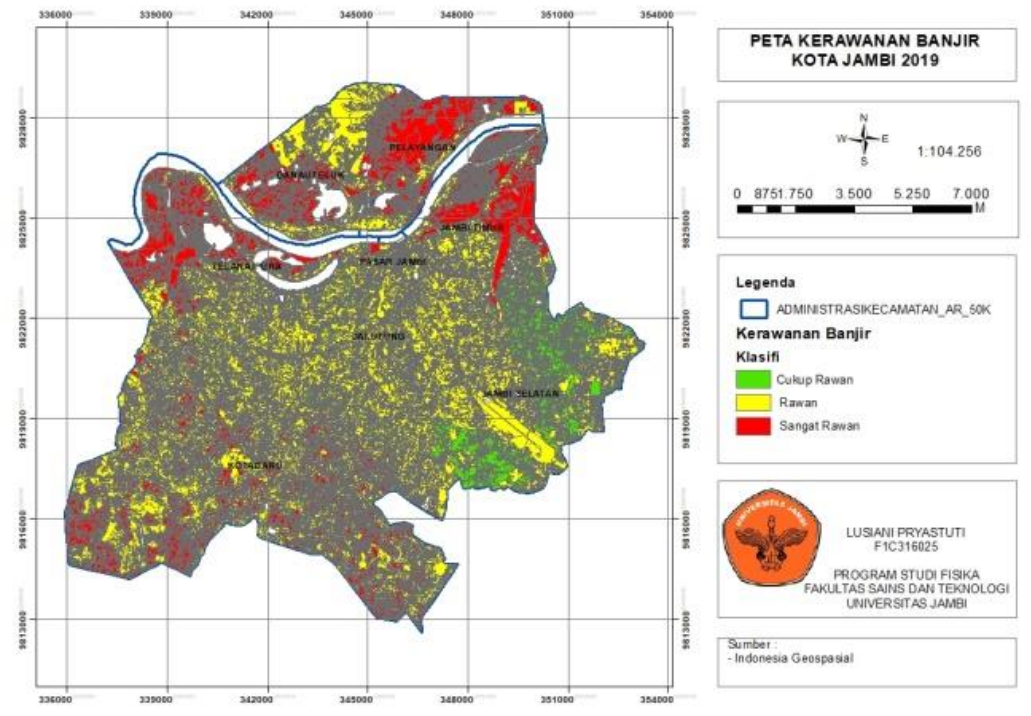

Gambar 7. Peta Kerawanan Banjir di Kota Jambi

\subsection{Persebaran Lokasi Rawan Banjir di Kota Jambi}

Kota Jambi merupakan salah satu kabupaten/kota yang ada di Provinsi Jambi, dimana daerah ini dapat dikatakan sering mengalami bencana banjir, khususnya untuk wilayah yang dekat dengan Sungai Batanghari seperti Kecamatan Telanaipura, Kecamatan Danau Teluk, Kecamatan Pelayangan, serta Kecamatan Jambi Timur. Namun yang paling rawan adalah Kecamatan Pelayangan. Selain datarannya yang rendah juga padat penduduk, sehingga air mudah tergenang dalam jangka waktu yang cukup lama dan menyebabkan terjadinya banjir. Luasan wilayah banjir untuk kategori sangat rawan adalah sekitar 3909.46 ha, untuk kategori rawan sekitar 9254.82 ha, sedangkan kategori cukup rawan atau dapat dikatakan cukup aman terjadi bencana banjir adalah sekitar 2849.14 ha. Bencana banjir umumnya 
dipengaruhi oleh kelerengan atau kemiringan lahan, ketinggian lahan, serta penggunaan lahan yaitu pemukiman penduduk dan tempat kegiatan lainnya. Berikut adalah tabel luasan untuk kategori banjir di Kota Jambi pada tahun 2019.

Tabel 5. Luasan Kategori Banjir di Kota Jambi

\begin{tabular}{cccc}
\hline No & Kategori & Luas (ha) & $(\%)$ \\
\hline 1 & Cukup Rawan & 2849.14 & 18 \\
2 & Rawan & 9254.82 & 58 \\
3 & Sangat Rawan & 3909.46 & 24 \\
\hline
\end{tabular}

\section{Kesimpulan}

Berdasarkan penelitian yang telah dilakukan dapat disimpulkan bahwa :

- Tingkat kerawanan banjir di Kota Jambi di klasifikan menjadi tiga kategori, yaitu cukup rawan, rawan, dan sangat rawan. Setengah wilayah kota Jambi berada pada kategori rawan banjir dengan luas 9254.82 hektar (58\%)

- Persebaran lokasi rawan banjir di kota Jambi khususnya untuk daerah sepanjang Sungai Batanghari termasuk kategori sangat rawan sedangkan untuk daerah yang cukup aman terhadap bencana banjir adalah Kecamatan Jambi Selatan

\section{Daftar Pustaka}

1. A. F. Astuti and H. Sudarsono, "Analisis Penanggulangan Banjir Sungai Kanci," J. Konstr., vol. 7, no. 3, 2020.

2. A. Rosyidie, "Banjir: fakta dan dampaknya, serta pengaruh dari perubahan guna lahan," J. Perenc. Wil. dan Kota, vol. 24, no. 3, pp. 241-249, 2013.

3. R. Rizkiah, "Analisis Faktor-faktor penyebab banjir di kecamatan tikala kota manado," SPASIAL, vol. 1, no. 1, pp. 105-112, 2015.

4. S. P. Nugroho, "Analisis Curah Hujan Penyebab Banjir Besar di Jakarta pada Awal Februari 2007,” J. Air Indones., vol. 4, no. 1, 2008.

5. A. M. Ginting, "Dampak ekonomi dan kebijakan mitigasi risiko banjir di DKI Jakarta dan sekitarnya tahun 2020," Info Singk., vol. 1, no. 1, 2020.

6. K. S. Pribadi and A. K. Yuliawati, "Pendidikan Siaga Bencana Gempa Bumi Sebagai Upaya Meningkatkan Keselamatan Siswa (Studi Kasus Pada SDN Cirateun dan SDN Padasuka 2 Kabupaten Bandung)," KRISHNA_S_PRIBADI_-_ITB.pdf, 2008.

7. E. Budiyanto, Sistem Informasi Geografis Menggunakan ArcView GIS. Penerbit Andi, 2002.

8. S. Renwarin, J. Lengkong, T. Sondakh, and J. Husain, "Pemetaan Wilayah Rawan Banjir Di Kota Manado Dengan Menggunakan Sistem Informasi Geografis," in COCOS, 2014, vol. 5, no. 3.

9. R. Rahmad, S. Suib, and A. Nurman, "Aplikasi SIG untuk Pemetaan Tingkat Ancaman Longsor di Kecamatan Sibolangit, Kabupaten Deli Serdang, Sumatera Utara," Maj. Geogr. Indones., vol. 32, no. 1, pp. 1-13, 2018.

10. A. Putra, A. Tri Ratnaningsih, and M. Ikhwan, "Pemetaan daerah rawan kebakaran hutan dan lahan dengan menggunakan sistem informasi geografis 
(Studi Kasus: Kecamatan Bukit Batu, Kab. Bengkalis)," Wahana For. J. Kehutan., vol. 13, no. 1, pp. 55-63, 2018.

11. F. A. Santoso, A. R. Putri, and R. A. Putra, "Arcgis based satellite image investigation to determine the risk of the earthquake disaster in north tapanuli district," Tek. J. Sains dan Teknol., vol. 17, no. 1, 2021.

12. N. Bahir, L. Yunus, and S. Sawaludin, "Pemetaan Risiko Kerentanan Wilayah Terhadap Banjir Di PesisirTeluk Kendari Provinsi Sulawesi Tenggara," JAGAT (Jurnal Geogr. Apl. dan Teknol., vol. 1, no. 1, pp. 41-50 